\title{
ANALYSIS OF A CULTURAL CHANGE IN A SPANISH TELECOMMUNICATIONS FIRM ${ }^{1}$
}

\author{
Enrique Claver; José L. Gascó; Juan Llopis and Enrique A. López
}

University of Alicante.

Business Organization Department

P.O. Box 99. 03580 Alicante (Spain)

Telephone and Fax 034.96.590.36.06

E. Mail: jl.gasco@ua.es

1 We want to express our gratitude to some people without whose invaluable help it would have been impossible to complete this paper. These people are Carlos Sáenz de Santamaría, Manager of Técnicas de Formación, S.A.; Valeriano Delgado, Provincial Head of Telefonica; Federico Castellanos, Human Resources Development Manager in Telefonica; Javier Barranco, Organization Manager in Telefonica; Antonio Ballester, Provincial Head of Human Resources in Telefonica; Manuel Palomino, former Provincial Secretary of Telefonica. We thank all of them for the documents they provided us with as well as for the kindness they showed during the interviews. 


\title{
ANALYSIS OF A CULTURAL CHANGE IN A SPANISH TELECOMMUNICATIONS FIRM.
}

KEY WORDS: Total Quality, Organizational Culture, Human Resources

Management

\begin{abstract}
This paper analyzes the efforts made by the Telefonica Group (the main Spanish firm in the telecommunications sector) to evolve from a bureaucratic culture to another oriented towards Total Quality and the customer. The need for this change came as a result of the liberalization in the telecommunications sector in the early nineties. This new context generated a problem that affected the basis of business itself: until then, they had subscribers to the telephone service; but from then on, they could have customers that would compare quality and price levels with those of rival firms.
\end{abstract}

Through an analysis of the internal documents generated in the process, and also by means of several interviews with executives and consultants who took part in the design and introduction of the change mentioned above, we study the validity and effectiveness of the steps taken. The methodology used by the firm was based on the "bubble-like" (from one division to the whole organization) and "cascadelike" (from the top management to the lowest levels) implementation systems, based on the support of strong training, communications and participation programmes.

\section{INTRODUCTION}

The elimination of barriers that make it possible to act according to a monopoly system is usually traumatic for any organization that has been 
operating within this type of framework. Experience shows that aspects such as labour layoff, the existence of aggressive competitors, price reductions and the impression of working under pressure are common in all cases. Experts in management state that the best way of facing up to changes is to anticipate them. In the present paper, we are going to analyze the efforts made by one of the largest Spanish firms in the telecommunications sector to change its management style and thus take up a position from which it could face competition in a free market.

In this respect, we must say that a change within an organization must be accompanied by a change in its members' individual behaviour. On the other hand, experts in management also claim that firms characterized by specific cultures can develop and be successful in certain environments, but when conditions change, the culture itself may end up leading the firm to failure and disappearance. For many years, bureaucratic cultures have favoured the development of great firms that have contributed to economic development in their countries; however, this kind of culture is no longer valid at present and must be replaced by others oriented towards two aspects, namely: the customer and quality. A great effort is required to succeed in changing a culture's organization and, logically, there are mechanisms and tools that make success easier. The aim of this paper is to contrast the validity of "cascade-like" and "bubble-like" mechanisms and, besides, to analyze the characteristics that training, communications and participation policies must have in their role as cultural change tools.

We are going to start by defining the concept of organizational culture. In that respect, we think that rather than analyzing its various definitions, it may 
make more sense to describe (even if it is only briefly) the essential characteristics that shape that notion of organizational culture. This would then act as a guide to know what specific activities are in keeping with the firm's "personality": Bosquet (1989) and Reitter and Ramanantsoa (1985); its existence is linked to the idea of sharing intentions: Hayes and Tomes (1988) and Robbins (1987); it is an empirical need to solve managerial problems: Camerer and Vepsalainen (1988); it is specific for each firm: Adams and Ingersoll (1985), Pearce and Robinson (1988) and Poiani (1987); it is an important way of communication: Singelis and Brown (1995); it has a qualitative sense: Alvesson (1989); chronology is related to its strength: Burack (1988) and Wren (1979); it is influenced by the environment in which it operates: Wilkins and Patterson (1988) and makes it possible to distinguish one group of people from another: Bollinger and Hofstede (1987).

Taking into account all the peculiarities of the term offered above, we propose a simple definition that includes them all: a set of values, symbols and rituals shared by the members of a certain firm that describe the way things are done within the organization when solving internal managerial problems, together with those related to customers, suppliers and the environment. Although many authors offer accurate definitions of cultural typologies, we are not going to deal with that aspect and will focus our attention on two clearly opposed models: the bureaucratic approach and the customer-oriented one.

The bureaucratic culture has been given many denominations depending on the specific feature authors wished to emphasize: technical rationality culture (Adams and Ingersoll, 1990); control culture (Ban, 1995); process culture (Deal and Kennedy, 1982); conformity culture (Feldman, 1985). Although 
we cannot specifically state that a bureaucratic culture is negative, the mere existence of this type of culture does seem to give rise to the following values, on the one hand, excessive conformism on the part of collaborators and, on the other, the assumption of more authority by the management. This results in passivity, mechanism and lack of new ideas, those being truly negative aspects. In this respect, Aucoin (1991), Bate (1990), Bozeman (1987), Kono (1990), Meyer (1985) and Morse (1986), among others, confirm that a bureaucratic culture entails a notion of stability which usually goes against the needs of the innovating process and, therefore, is opposed to any sort of changes.

As regards customer-oriented cultures, following Aaker (1989), Ansoff (1979), Deshpande and Webster (1989), Firnstahl (1984), Ishizuna (1990), Schein (1992), Serizawa (1989) and Stewart and Clarke (1987), we can highlight the following characteristics: A) Contact with customers is frequent. B) Customers' problems are carefully analyzed. C) Keeping delivery terms has priority. D) Quick service is assumed by all corporate members. E) The behaviour towards customers is usually regulated beforehand. F) The ultimate aim of the tasks and activities carried out is to offer the customer a useful service. G) The organization is assessed by the quality of the service delivered with the resources available. H) Customer service will be a cultural value when all the organization members share it. I) High-quality service is needed. J) Service quality requires organization really approaches its customers. K) Customers hold a priority position in the corporate set of values.

A way of achieving this disposition towards customers is through Total Quality Programmes. Unfortunately, some practitioners confuse Total Quality and certifications, for example, through ISO 9000). However, they forget that 
certification is not enough and can not guarantee that all organization members assume that quality is the essential competitive advantage (Czuchry, Hyder, Yasin and Mixon, 1997; Handfield and Ghosh, 1994; Hind, 1996; Mallak, Bringelson and Lyth, 1997; Shadur, 1995; Shields, 1994; Shih and Gurnani, 1997; Van Donk and Sanders, 1993).

Certification is only a step prior to Total Quality and, in this respect, its obtention is interesting, but if we want to achieve quality and excellence, the matter must be dealt with in more depth (Bowen, 1996; Johnson, 1991; Maccoby, 1993; McNabb and Sepic, 1995; Shirley, 1997; Sinclair and Collins, 1994; Southern and Murray, 1994). There is not a clear methodology to achieve it, and the reality of business shows that different ways have been used; nevertheless, we put forward the hypothesis that the use of "bubble-like" introduction mechanisms as well as "cascade-like" implementation mechanisms, with the support of the right training and communications policies that generate participation and commitment within the project, is a valid system to succeed in changing from a bureaucratic culture into a customer-oriented one.

As regards the "bubble-like" introduction, especially in large firms, different subcultures exist that can be taken advantage of in order to transform the organization's global culture. We must support the department or section that shows desirable values and then export the desirable subculture into the rest of the firm. As for the "cascade-like" introduction, we have to make sure that culture reaches the top management, from where it then gets to executives, finally arriving at the rest of the staff. Concerning tools, there are mainly two: training and communications. However, we think the former will be useful when, instead of transmitting knowledge, it concentrates on creating a language 
and a set of favourable conditions for those involved in the process so that they will be able to succeed by themselves. This is why people in charge of giving this training must make sure they do not become mere speakers that refer to more or less interesting subjects. Instead, they should be the catalysts of a change process that must be assumed by the people involved as well. It will be the right communications policies that will favour everyone's implication in the new project. In this sense, holding conventions with a certain regularity can be a good instrument, along with the distribution of internal information bulletins.

Taking as a reference point the study of one case, namely that of the Telefonica Group, we intend to analyze the chances of success for a cultural change managed in the way we have just described.

\section{THE TELEFONICA GROUP}

At present, when we talk about the Telefonica Group, we are referring to a parent company that exploits the telephone service in several countries, and to a group of enterprises dedicated to various businesses related to telecommunications. Telefonica exploited Spain's telephone service in a monopoly system between 1924 and 1998, the moment in which the liberalization of the sector takes place, and Telefonica starts delivering its service within a competition framework. In 1998, its workforce exceeds 103,000 employees and its profits amount to 217,000 million pesetas. It is the most important value in Madrid's Stock Exchange and is listed in the Stock Markets of New York, Tokyo, Paris and London. The number of clients is above 40 million, more than half of them in South America. Nowadays, it still maintains a clear leadership in Spain's telecommunications sector, having also consolidated its international presence. 
However, the firm has gone a long way before reaching this leadership status in the Spanish and Portuguese-speaking world; it has overcome different stages and faced numerous transformations in its environment and has undertaken important reforms regarding its internal management, especially in the last decade of this century. Among the transformations it has had to go through, we must emphasize customers' greater demands and pressure exerted by competitors after the liberalization. Other firms, especially North American and European ones have experienced these changes in similar conditions, although changes took place later in the case of Telefonica. Examples of how other companies have faced changes like the ones we are explaining can be found in: Barnes (1987); Clark (1993); Davey and Shepherd (1992); Graetz (1996); Hoskinsson, R.E.; Alexandre, J.; Blackley, T. et al. (1998); Kanter (1991); Katz (1995); Smith, Barnard and Smith (1986); Smith (1994); Swierczek (1992) and Tunstall $(1983,1986)$.

In the late eighties, ten years before the deregulation process started, the top management considered that the forthcoming changes made it necessary to define a new task for the firm, namely "being identified by its current and potential clients as their favourite provider of telecommunications, voice, data, sound and image services".

This was not an easy challenge for an organization which had been operating in a stable regulated environment for many years and had developed a strong bureaucratic culture in which all its employees had a job for life guaranteed. 
At present, we can declare this aim has been reached. Achieving it has not been easy though. However, there are some magnitudes, especially those related to staff numbers, which show that the part of the way the firm still has to cover is not an easy one. Anyway, there is no doubt that the Telefonica Group has put into practice very significant modifications concerning the way in which a large organization has to be managed, and among the most important ones we can mention making all its personnel aware of the forthcoming changes and of the need for behaviours to be changed. Liberalization in the sector was round the corner and it was necessary to face a new period, with a new problem which was at the basis of business: until then, they had had telephone service subscribers and in the future, they would have customers that would compare quality and price levels with those of competitors.

One of the group's organizational units, namely Alicante's Territorial Head Office, was especially important in this change process that brought in new behaviours and beliefs, and in short, a new culture. This unit represented the starting point for management practice schemes and staff policies that would incrementally be developed later ("bubble-effect") in the firm as a whole.

\section{CERTIFICATION AS A STARTING POINT ON THE WAY TOWARDS TOTAL QUALITY}

In 1989, Alicante's office was just a division of the group with 1,200 employees. At that time and due to its characteristics, it was a complex division, but also a very profitable one with a large growth potential. These circumstances encourage the Central Office to approve an investment plan of 15,000 million pesetas in order to meet the firm's development needs. However, top managers in Alicante were aware of the fact that improvements in 
equipment and infrastructures were not going to be enough. They were convinced that structures, behaviours and values had to be modified and adapted; in other words, quality management was needed. This is why the top management in Alicante reached the conclusion that it was necessary to walk in search of Total Quality. One of the first steps on the way to achieving that new management model was based on some courses about Management and Total Quality given to the Management Board. Shortly after that, studies on training needs showed it was convenient to extend these courses to the next hierarchical levels. For three years, courses with similar contents and with an identical approach were given to all the members of the middle line.

Early in 1993, it was decided to materialize this by moving ahead towards Total Quality and thus, a draft of the Business Project for Total Quality (BPTQ) was drawn up, according to which Total Quality is defined as the ideal means to succeed in grouping all the employees together around a common ambition, namely "doing things right first time, from the customer's point of view, at the lowest possible cost: in every functional area, by every intervening person and in every task being carried out".

This draft makes it clear that Alicante's Management Board considers its task is "to succeed in becoming the favourite telecommunications service provider, these services being delivered with the highest quality standards, acknowledged by the customer, and at the lowest possible cost". In order to be able to accomplish this task, a set of values is defined that can encourage its employees to fix the objectives and to define the practices that make it possible to achieve those objectives. These values are: “(1) The convergence of interests between the firm's staff and its clients. 2) Clients must identify the enterprise 
for the capacity of its human resources to overcome even its technological resources. 3) Total Quality will be reached through the staff's teaching and exemplary attitude in their working practice".

Middle managers and bottom line employees would have viewed this work as a passing fashion if the Management Board had not made such a great effort in terms of internal communications, the aim of which was to involve all the organization members in the change process. Following a cascade-like procedure, in which all the members of the middle line participate, the draft of the $B P T Q$ is submitted for examination and consultation by $85 \%$ of the employees. An explanation is given about the working system used to draw it up and the employees' opinion about the contents of the BPTQ is collected. The suggestions they gathered are used to prepare the final document, which is approved by Alicante's Management Board and the Central Quality Department in Madrid.

At this stage, the objectives fixed in the search of a sufficient quality level are to succeed in achieving "recognition by the current customers; dominance in a market based on high competitiveness levels; employees' satisfaction and pride and the business certificate of registration".

Once the BPTQ was approved by the Central Head Office in the middle of 1993, the communications action was complemented. The same set of "cascadelike" meetings is repeated, in which the $B P T Q$ is read and commented upon to all the staff through their managers, a process which is completed late that year. A later survey highlighted that $90 \%$ saw their ideas reflected in the definitive text, which guarantees the subsequent identification with a project in 
which one has participated.

Simultaneously with this process, a Quality Manual and other operating procedures start to be drawn up. This text collects the regulations that are binding on the whole organization and have a bearing on services, all of it oriented to ensuring quality. All the staff are given training on quality at different levels (concepts, tools, processes, etc.). Finally, the Plan is subjected to the mandatory quality audits, as a result of which the ISO 9000 Certification is obtained in June 1995.

\section{FROM CERTIFICATION TO TOTAL QUALITY}

Unlike many firms, in which obtaining the ISO 9000 certification is understood as the achievement of a sufficient quality level and, implies, in fact, the end of the process, Alicante wanted to move further ahead in that direction. The Management Board considers that "this is only the beginning of the way that will lead us to obtain Total Quality and certification is not enough, a new management system had to be implemented which is more in keeping with the professional and business future we have to face".

This way, and still waiting to be subjected to the mandatory audits, the Management Board opens two new action lines at the beginning of 1994. On the one hand, A Quality Plan is established, with annual objectives, in which are included the criteria taken from the EFQM (European Foundation for Quality Management). On the other, along with the top management in Madrid, the Management Board starts to design a Programme for the Development of Middle Line Managers, which is initially put into practice in Alicante and would later be progressively implemented all over Spain. 
The purpose of this programme was not so much providing knowledge on technical or managerial matters; its aim was rather the creation of more favourable and positive conditions for those interested themselves in being able to "improve the task of day-to-day management, according with those Total Quality Parameters that they all had agreed".

With this aim, it was considered necessary that participants should have a triple commitment dimension:

- Commitment with themselves (Since management is my job, I must develop management skills).

- Commitment with the team (My task must be carried out through my team, which I have to develop).

- Commitment with the company (My team's as well as my objectives are part of the firms's general objectives).

The first stage of the programme is developed before the summer of 1994. During this stage, a self-diagnosis is made of the problems that managers find "on doing their everyday tasks", together with the prospects for its possible evolution in the near future. One of the first steps they took was the organization of some meetings in which a self-diagnosis of the situation was made and the action guidelines were established. Later, all the members of the middle line took part in this stage by completing the self-diagnosis and by finishing the design of the programme's later contents. The different teams that were set up in the working sessions had to answer the following questions: 
- "What image do you have of yourselves as managers?

- Which factors can lead Telefonica to reach great success in the year 2010?

- Which factors can lead Telefonica to failure?

- Which aspects strike you as being most strange in the current management style?

- In your view, which are the characteristics that Telefonica managers must have?"

As regards the image they had of themselves, the following expressions can be highlighted:

- Islands. We are too scattered and we do not have enough communication with each other.

- Concentric circles. The large circle represents the whole firm; we are the small circle. We move about floating all around the large circle.

- Firemen. Our main task is fire extinction, we have to improvise all the time and seldom know what is going to happen the next day.

- Beasts of burden. We are like animals, we bear the burden, but we move forward; we sweat blood. Only the Provincial Head's personal exemplary attitude makes us continue to endure this situation.

- Trapped waves. We are struggling to achieve respect for the individual, communication, flexibility. Pressures prevent us from expanding.

- Steam hammer. We feel under great pressure both from our 
superiors and from objectives, regulations and results.

Concerning factors that would lead Telefonica to reach success, the following ones stand out: advanced technology; market diversification; adapting to the customer's needs; real decentralization; the customer as the basis; flexible regulations; shared, well-known objectives; everyone's involvement in reaching success; adjusting the workforce according to real needs; increased productivity. As can be seen, these aspects coincide with the characteristics of customer-oriented cultures.

As the causes of potential failure were mentioned: inappropriate planning; employees' lack of involvement; too many hierarchical levels; insufficient investment in technology; not being able to adapt to the market; inappropriate business alliances. All these factors were directly related to the mistakes they were making at the time and were the typical ones in bureaucratic cultures.

As regards the negative aspects in the firm's operation, the following ones were highlighted: dispersion of management units which needed coordination; decisions depended on the centralized authority; excessive internal bureaucracy; use of obsolete internal communications systems; general dissatisfaction with their pay; lack of coordination between functional areas; too much paper and limited use of office automation; lack of social awareness within the organization.

Concerning the characteristics the ideal Telefonica manager should have, the following ones were collected: involvement in the firm; receptivity to 
change; constructive critical spirit; capacity to work in a team; being ready to listen; hope and the capacity to transmit it; being able to collaborate; ability to analyze and synthesize matters; initiative and decision; being able to delegate in others; liking of the job and an exemplary attitude at work.

Once these matters had been analyzed, the middle managers themselves were made to identify the skills they needed to develop, trying to take advantage of the factors for success they had previously defined and to minimize the causes of potential failure. They would thus contribute to the disappearance of those abnormal aspects they had detected and therefore, would get closer to the ideal manager's profile they had designed themselves. In other words, which education and which training they needed to change their behaviour as managers. The different requests were grouped together and distributed into six formative blocks or areas: fixing objectives, teamwork, personal work organization, analysing and solving problems, motivation and communication. After identifying these blocks, all the members of the middle line went through the corresponding formative sessions.

After the summer of 1994, the Management Board decides to support this training action with an ambitious communication's programme. The objective was to design an action plan for 1995 on which a general consensus was reached, with the symbolic and real aim of moving ahead towards a Convention in which general agreement would be reached on actions to be undertaken in 1995 so that the desired cultural change could take place.

THE PERSONNEL INTEGRATION PROCESS INTO THE FIRM'S PROJECT 


\section{FOR QUALITY}

The slogan they agreed was: "A new management style". The Action Plan for 1995 had to be specified during this Convention. The preparation of this plan was intended to represent quite an event and it would lead the middle line managers to make a joint reflection on how to conjugate management needs, the current ones and those foreseen in the near future: putting into practice the knowledge, skills, attitudes and new values that had been considered in the different formative sessions held until then. At the same time, a decision was made to facilitate the participation of the middle line, as a result of which a feeling of ownership, prominence and control over the Convention's preparation process was generated. The underlying idea, as was exposed by the Provincial Head Manager is that: "the best mobilization is that based on collective participation". We have identified five stages that followed until the end of the process:

\section{1) Preparation and written definition of the Action Plan for 1995.}

It consisted in the preparation and research on the objectives fixed as tasks for 1995 and the way of achieving them. When this document was being drawn up, they tried to make sure objectives were drawn up from a double perspective: a) that of the task or the vertical objectives in each area and b) that of relationships and horizontal management objectives that affect all the areas or the way of achieving the objectives in question.

\section{2) Written definition of a Commitment Plan.}

The middle line managers got together to draw up a document containing commitments and suggestions that would be taken into account for the preparation of the final action plan and with which an attempt was made to increase involvement in the change process. In order to make both the 
discussion and everyone's participation easier, seven subjects were put forward: 1) Management Board's objectives and commitments. 2) Middle line managers' objectives and commitments. 3) Objectives and commitments of those in charge of the different operational managers. 4) Role of the manager and workteam. 5) Everyone's involvement in Total Quality. 6) Relationships between working units. 7) Vertical communication.

Thus, six groups of middle line managers and one of executives were set up. They all met in several sessions, in which they had to reflect on the following questions:

1) What do we understand by everyone's involvement in Total Quality?

2) How can we improve the relationships between working units and how can we improve vertical communication?

3) What is the role of managers in the new management style and how do they involve their workteam?

Once the different groups finished their work, they were asked to propose three actions for each of the subjects that could represent a commitment, for all this group of the middle management, to be carried out in their day-to-day management experience. The characteristics of these commitments/actions were: easy to understand; they were expressed by means of verbs in the infinitive; they were observable and measurable and should cover the largest possible number of sections in the question-answering process. These three actions that were put forward would have to be presented in an address by two volunteers of each group in the Convention. The action guidelines on which consensus was reached were the ones we have summarily reflected in Table 1. 
The combination of all these actions/commitments of the various groups and for each of the subjects should mean a change in the management style and in the way command was implemented: "A new management style".

\section{Take in Table I}

\section{3) Holding the Convention}

The Convention consisted in an intensive working session held in a hotel located in a tourist resort 30 kilometers away from Alicante City (Alicante City is the capital of the province of Alicante). Firstly, a speaker of each team presented in front of all the participants the different action lines they had put forward for each of the subjects that had been fixed. Later, the assembly was divided into commissions that were going to debate on the viability, timeliness and the way of implementing each of those actions they had exposed through the different reports they had presented.

The results of the debates in the different commissions were collected in a series of panels, which were exposed to all those attending the Convention by each of their respective coordinators. Next, all the participants proceeded to vote for those actions they considered to be both the most necessary and the most feasible ones. The Convention finished with the presentation of the result obtained by each of the actions, a panel which clearly reflected to what extent all the managers had got involved. In this way, it was defined what managers and executives understood as their "new management style" and it became clear what they had to do for this new style to be reflected in their activity, always with the three-fold perspective of commitments (with the firm, with their team and with themselves). The challenge lay now in each manager's capacity 
to try and adapt this action plan to their work unit, to their team, as a programme for permanent improvement in management all year round, in their feeling responsible and in their will to include the above-mentioned points in that action plan.

\section{4) Diffusion of the document among the staff}

The Management Board, taking these agreements into account, collected different suggestions with which they put forward, after the corresponding debates, a final document that came to be known as Action Plan for 1995. In that document were fixed the actions that would obligatorily be carried out during that year: 1) Analyzing processes. 2) Creating and using communications systems. 3) Designing and applying participation methods. 4) Providing training. 5) Spreading quality culture. 6) Making objectives and communicating them. 7) Stimulating mutual knowledge between areas. Besides this, the document reflected the specific objectives that were to be covered, the tasks that had to be carried out in order to implement them and the terms for their execution, apart from establishing who was responsible for each task.

This document was later officially transmitted to every single member of the middle line. In turn, they transmitted it to their teams of collaborators, taking the necessary steps for its proper communication so that an agreement was reached by the staff in order to jointly achieve the objectives that had been set up. They proceeded to the diffusion of the written version of the document in all working areas of the firm.

\section{5) Checking results and reviewing objectives}

In order to assess what had been achieved, a survey was made at the end 
of 1995 among all the managers and executives in the province, so that they could establish their own appraisal of the level of achievement of the different actions and objectives, assessing as well in which aspects and to what extent the management job had been modified. The information that was obtained would be presented in a Convention in February 1996.

The response index for the above-mentioned survey reached $90 \%$. It can be deduced from this that $75 \%$ of the interviewees were sufficiently satisfied with the results obtained regarding the action plan and the $92 \%$ felt they were backed up to carry it out.

As regards the degree of achievement, we must point out that the following actions were covered: process analysis, design and application of participation systems; training; spreading the quality culture and making the objectives as well as their results known at each level.

Analyzing processes made it possible to recover several activities that were controlled by subcontractors. As regards training, both the objective of personalizing formative demand and that of improving the training supplied were achieved. As for the spreading of quality culture, we can assume the aim was reached. At basic levels, we can state that the diffusion was wide enough, although this should be one of the aspects to be subject to permanent in-depth improvement, due to its dynamic nature. However, the staff's contribution levels as regards improvement initiatives and non-quality points, was quite far from what was initially expected.

The points where the degree of satisfaction with the levels obtained was 
low were the creation and use of communications systems and the encouragement of inter-area knowledge. As regards the former, a bulletin called Telefonicalidad was set in motion. This bulletin proved to be a useful downward communications instrument for items of information that needed to become widespread, but it could not represent the only and exclusive communications channel. Experience showed that it should be complemented by meetings and communications at the workplace, an activity with which mainly middle line managers did not feel satisfied.

As regards inter-area knowledge and coordination, the issues of the internal bulletin Telefonicalidad offered descriptions of the tasks at every single functional unit, interviews with the people in charge of these units as well as news about them. Despite all this, we can say cooperation levels did not live up to the expectations. The reasons why this objective was not achieved, as was shown by the survey, were: a) the lack of structured channels that were appropriate; b) the absence of a disposition to dialogue on the part of the different functional groups; c) the existence of frictions between departments, because they thought their interests did not coincide completely; d) the lack of interest in what the others do and e) the dispersion of organizational units. As can be seen, the lack of suitable communication between executives and managers came to the surface once again.

Although the degree of satisfaction after the implementation of the Action Plan for 1995 was quite high, the following difficulties stand out among the ones managers had to face when it had to be put into practice: demotivated staff $85 \%$, technical impossibilities $86 \%$, lack of help from the management $74 \%$, impossibility of everyday tasks $88 \%$; objectives that were 
not classified and specified 79\%.

After seeing the positive results obtained, the top management at the Telefonica Group decided to set in motion the process that had started in Alicante in the rest of divisions all over Spain, taking into account that the results derived from the self-diagnosis (a poor public service mentality, not knowing the objectives, the staff's low degree of involvement, etc.) were almost identical in all divisions. At this stage, we can declare that it was an important step towards the consolidation of a culture based on Total Quality and a good way of preparing the organization to treat its customers differently.

The firm has continued to make efforts until the present day, which has made possible Telefonica's current status as a leading multimedia service firm both in Spain and in the Spanish-speaking cultural context, a success that has been based on a Total Quality Culture and has been complemented by the appropriate strategic alliances. As a result of this, the Telefonica Group is preferred by many customers when it comes to having access to the many great advantages and options that are offered by the information society and has simultaneously acted as an essential support instrument for the competitiveness of numerous firms.

\section{FINAL CONSIDERATIONS}

To conclude, we must say that the introduction of a Total Quality Culture, with its implicit orientation towards the customer, is a complex subject and requires a long-term approach. In the specific case we have studied, it becomes obvious that this firm has taken enough and important 
steps to move ahead in that direction, that executives and managers in Alicante considered it to be essential for the management of the firm and, above all, with a view to Telefonica's future and their own professional prospects. This has become noticeable in the fact that numerous tasks and functions are now more agile, which has been perceived by customers. At present, managers can communicate better and besides, there is undoubtedly a higher degree of involvement on the part of the staff in achieving customer satisfaction. Using the words of those involved in this process: we are starting to stop seeing subscribers in order to start seeing clients and, therefore, we are getting ready to compete in the tough telecommunications market.

Thus, we reach the conclusion that the methodology used by Telefonica, the "bubble-like" implementation scheme (from one division to the whole organization), starting in Alicante's Territorial Head Office, along with the "cascade-like" introduction mechanism (from the top management to the lowest levels), supported by the correct training, communications and participation programmes has proved to be a valid system when it comes to achieving a cultural change in the terms described in this paper.

\section{REFERENCES}

Aaker, D.A. (1989), "Managing assets and skills: The key to a sustainable competitive advantage", California Management Review, Vol. 31 No. 2, pp. 91-106.

Adams, G.B. and Ingersoll, V.H. (1985), "The difficulty of framing a perspective on organizational culture", in Organizational culture, P.J. Frost et al. (eds.), pp. 223-234, Beverly Hills, Sage.

Adams, G.B. and Ingersoll, V.H. (1990), "Culture, technical rationality, and organizational culture", American Review of Public Administration, Vol. 20 No .4, pp. 285-303. 
Alvesson, M. (1989), "Concepts of organizational culture and presumed links to efficiency", Omega. The International Journal of Management Science, Vol. 26 No.3, pp. 323-333.

Ansoff, I.H. (1979), Strategic Management, MacMillam, London.

Aucoin, P. ( 1991), "The politics and management of restraint budgeting", in The budget maximizing bureaucrat: appraisals and evidence, A. Blais and S. Dion (eds.), pp.119-141, Pittsburgh University Press.

Ban, C. (1995), How do public managers manage? Bureaucratic constraints, organizational culture, and the potential for reform, Jossey Bass, San Francisco.

Barnes, Z. E. (1987), "Change in the Bell System", Academy of Management Executive, Vol.1 No.1, pp. 43-46.

Bate, P. (1990), "Using the culture concept in an organization development setting", The Journal of Applied Behavioral Sciences, Vol. 26 No.1, pp.83-106.

Bollinger, D. and Hofstede, G. (1987), Les différences culturelles dans le management, Les Editions d'Organisation, Paris.

Bosquet, R. (1989), Fondements de la performance humaine dans l'entreprise, Les Editions d'Organisation, Paris.

Bowen, P.W. (1996), “The need for quality cultures”, Training for Quality, Vol. 4 No. 2, pp. 14-18.

Bozeman, B. (1987), All organizations or public, Jossey Bass, San Francisco.

Burack, E.H. (1988), Creative human resource. Planning and aplications. A strategic approach, Prentice Hall, New Jersey.

Camerer, C. and Vepsalainen, A.(1988), "The economic efficiency of corporate culture", Strategic Management, Vol. 9, pp. 115-126.

Clark, T. (1993), "ATT listens to customer signals", Business Marketing, Vol. 78, No. 11, pp. 22-24.

Czuchry, A.J., Hyder, C., Yasin, M. and Mixon, D. (1997), "A systematic approach to improving quality: a framework and a field study", International Journal of Quality \& Reliability Management, Vol. 4 No. 9, pp. 876-898.

Davey, J. and Shepherd, D. (1992), “BT's wheel of fortune”, Personnel Management, Vol.24 No.1, pp. 40-43.

Deal, T.E. and Kennedy, A.A. (1982), Corporate cultures, Addison Wesley, Reading, Massachusetts. 
Deshpande, R. and Webster, F.E. (1989), “Organizational culture and marketing: Defining the research agenda", Journal of Marketing, Vol. 53 No.1, pp. 3-15.

Feldman, S.P. (1985), "Culture and conformity: An essay on individual adaptation in centralized bureaucracy", Human Relations, Vol. 38 No. 4, pp. 341-356.

Firnstahl, T.W. (1984), "Corporate culture and competitive strategy", in Strategic human resource management . C.J. Fombrun, N.M. Tichy and M.A. Devanna (eds.), 203-216, Wiley, New York..

Graetz, F. (1996), "Leading strategic change at Ericsson”, Long Range Planning, Vol. 29 No. 3, pp. 304-313.

Handfield, R. and Ghosh, S. (1994), "Creating a quality culture through organizational change: a case analysis", Journal of International Marketing, Vol. 2 No. 3, pp. 7-36.

Hayes, M. and Tomes, A. (1988), Practical operations management, Philip Allan, London.

Hind, M. (1996), "Are the cultures required to attain ISO 9000 and total quality management mutually exclusive?", Training for Quality, Vol. 4 No.2, pp. 25-29.

Hoskinsson, R.E.; Alexandre, J. Blackley, T. et al. (1998), “Teléfonos de México", in Strategy, Process, Content, Context. An International Perspective, B. Wit and R. Meyer (eds.), 1156 - 1172, International Thomson Business Press, New York..

Ishizuna, Y. (1990), "The transformation of Nissan. The reform of corporate culture", Long Range Planning, Vol. 23 No.3, pp. 9-15.

Johnson, J. (1991), "The culture clock: TQM and doing the right thing right at the right time", Journal for Quality and Participation, Vol. 14 No.6, pp. 10-14.

Kanter, R. M. (1991), "Championing change: An interview with Bell Atlantic's CEO Raymond Smith", Harvard Business Review, Vol. 69 No. 1, pp. 118-130.

Katz, J. E. (1995), "Transforming corporate culture in the US telecommunications industry: Notes on social engineering", Human Systems Management, Vol.14, pp. 21-38.

Kono, T. (1990), "Corporate culture and long range planning”, Long Range Planning, Vol.23 No. 4, pp. 9-19.

Maccoby, M. (1993), "To create quality, first create the culture”, ResearchTechnology Management, Vol. 36 No. 5, pp. 49-51.

Mallak, L.A., Bringelson, L.S. and Lyth, D.M. (1997), "A cultural study of 
ISO 9000 certification", International Journal of Quality \& Reliability Management, Vol.14 No. 4, pp. 328-348.

McNabb, D.E. and Sepic, F.T. (1995), "Culture, climate, and total quality management: Measuring readiness for change", Public Productivity \& Management Review, Vol. 18 No.4, pp. 369-385.

Meyer, M. (1985), Limits to bureaucratic growth, Walter de Gruyter, Berlin.

Morse, C.W. (1986), "The delusion of intrapreneurship", Long Range Planning, Vol. 19 No. 6, pp. 92-95.

Pearce, J.A. and Robinson, R.B. (1988), Strategic management. Strategic formulation and implementation, Irwin, Homewood, Illinois.

Poiani, M. (1987), La cultura d'impresa. Come mettere a punto soluzioni, Franco Angeli, Milan.

Reitter, R. and Ramanantsoa, B. (1985), Pouvoir et politique: Au dela de la culture d'entreprise, McGraw Hill, Paris.

Robbins, S.P. (1987), Organization theory, structure, design and aplications,: Prentice Hall, New Jersey.

Schein, E.H. (1992), Organizational culture and leadership, Jossey Bass, San Francisco.

Serizawa, Y. (1989), "Planning for growth in a Japanese business", Long Range Planning, Vol. 22 No. 2, pp. 20-26.

Shadur, M.A. (1995), "Total quality. Systems survive, cultures change", Long Range Planning, Vol. 28 No.2, pp. 115-125.

Shields, M. (1994), "Total quality management. Another mast to string your flag to, or a means to change a company's culture?", The TQM Magazine, Vol.6 No.5, pp. 45-46.

Shih, L.C. and Gurnani, H. (1997), “Global quality management programmes: How to make their implementation more effective and less culture dependent", Total Quality Management, Vol.8 No.1, pp. 5-31.

Shirley, B. (1997), "Total quality in ICS". The TQM Magazine, Vol. 9. No.1, pp. 29-35.

Sinclair, J. and Collins, D. (1994), “Towards a quality culture?”, International Journal of Quality \& Reliability Management, Vol. 11 No.5, pp. 19-29.

Singelis, T.M. and Brown, W.J. (1995), "Culture, self and collectivist communication; Linking culture to individual behavior", Human Communication Research, Vol. 21, pp. 354-389. 
Smith, P. E.; Barnard, J. M. and Smith, G. (1986), "Privatisation and cultural change: A case study of management development in British Telecom", Journal of Management Development, Vol. 5 No. 2, pp. 51-61.

Smith, R. W. (1994), "Driving change at Bell Atlantic", Planning Review, Vol. 22 No 5, pp. 25-27.

Southern, G. and Murray, A.U.(1994), "Quality information management: The way to a better company culture", Information Management \& Computer Security, Vol. 2 No. 2, pp. 32-35.

Stewart, J. and Clarke, M. (1987); "The public service orientation: issues and dilemmas", Public Administration, Vol. 65 No.3, pp. 161-177.

Swierczek, F. W. (1992), "Management of change in telecommunications: A cultural approach", International Journal of Technology Management, Vol.7 No. 6-8, pp. 409-423.

Tunstall, W. B. (1983), "Cultural transition at AT\&T”, Sloan Management Review, Vol. 25 No. 1, pp. 15-26.

Tunstall, W. B. (1986), "The breakup of the Bell System: A case study in cultural transformation", California Management Review, Vol. 28 No. 2, pp. 110-124.

Van Donk, D.P. and Sanders, G. (1993), “Organizational culture as a missing link in quality management", International Journal of Quality \& Reliability Management, Vol. 10 No. 5, pp. 5-15.

Wilkins, A.L. and Patterson, K.J. (1988), "You can't get there from here: what will make culture-change projects fail", in Gaining control of the corporate culture. R.H. Kilmann, M.J. Saxton and R. Serpa (eds.), pp. 262-291. San Francisco: Jossey Bass.

Wren, D.A. (1979), . The evolution of management thought. New York: Wiley. 


\section{Table I. Proposals for action lines in order to achieve the objectives set up.}

\begin{tabular}{|c|c|}
\hline Objective. & ACTION LINES \\
\hline $\begin{array}{l}\text { 1) Management Board's } \\
\text { objectives and } \\
\text { commitments. }\end{array}$ & $\begin{array}{l}\text { Optimizing the use of resources. } \\
\text { Trying to recover activities that are currently outsourced. } \\
\text { Encouraging participation at every level in the organization }\end{array}$ \\
\hline $\begin{array}{l}\text { 2) Middle line } \\
\text { managers' objectives } \\
\text { and commitments. }\end{array}$ & $\begin{array}{l}\text { Communicating objectives, results follow-up and diffusion schemes. } \\
\text { Adapting the training to the real needs. } \\
\text { Knowledge of needs and problems among working units. }\end{array}$ \\
\hline $\begin{array}{l}\text { 3) Objectives and } \\
\text { commitments of those } \\
\text { in charge of the } \\
\text { different departments. }\end{array}$ & $\begin{array}{l}\text { Making sure every team member shares the group's success and } \\
\text { failures. } \\
\text { Strengthening team cohesion by generating confidence in the } \\
\text { group. } \\
\text { Promoting initiatives and suggestions. Making the management's } \\
\text { proposals and objectives "digestible" for the team. Collecting, } \\
\text { presenting and defending them. }\end{array}$ \\
\hline $\begin{array}{l}\text { 4) Role of the manager } \\
\text { and workteam.. }\end{array}$ & $\begin{array}{l}\text { Designing a training plan which is agreed with each specific } \\
\text { employee and can cover his/her limitations. } \\
\text { Setting up work meetings to draw the group together and give it } \\
\text { feedback. } \\
\text { Support and awareness as regards formulas and commitments, by } \\
\text { collecting suggestions. } \\
\text { Creating improvement groups. }\end{array}$ \\
\hline $\begin{array}{l}\text { 5) Everyone's } \\
\text { involvement in Total } \\
\text { Quality. }\end{array}$ & $\begin{array}{l}\text { Preparing a quality bulletin and spreading the concept of quality. } \\
\text { External suppliers' action. } \\
\text { Increasing the number of quality groups through periodical } \\
\text { meetings. }\end{array}$ \\
\hline $\begin{array}{l}\text { 6) Relationships } \\
\text { between working units }\end{array}$ & $\begin{array}{l}\text { Promoting mutual knowledge between areas. } \\
\text { Encouraging inter-area communication. } \\
\text { Developing a positive attitude of mutual collaboration between } \\
\text { areas in order to achieve objectives. }\end{array}$ \\
\hline $\begin{array}{l}\text { 7) Vertical } \\
\text { communication. }\end{array}$ & $\begin{array}{l}\text { Improving information channels, so that once refined, that } \\
\text { information is properly distributed to each manager in time and } \\
\text { through the right channel. Feedback/suggestions. } \\
\text { Setting up instruments for the periodical diffusion of information of } \\
\text { general interest. } \\
\text { Studying and adapting the communications means available to the } \\
\text { real needs in the different units. Updating computer equipment. }\end{array}$ \\
\hline
\end{tabular}

